\title{
Effect of moisture content on tunnel fire resistance of self-compacting concrete coated with aerogel mortar
}

\section{Xinjie Wang}

Department of Civil Engineering, Changzhou University, Changzhou,

China

Pinghua Zhu

Department of Civil Engineering, Changzhou University, Changzhou, China

\section{Shuqi Yu}

Department of Civil Engineering, Changzhou University, Changzhou, China; School of Civil Engineering, Southeast University, Nanjing, P.R. China
Hui Liu

Department of Civil Engineering, Changzhou University, Changzhou, China (corresponding author: liuhui@cczu.edu.cn)

Yanlong Dong

Changzhou CRCC Urban Construction Component Co., Ltd, Changzhou, China

\section{Xiaoyan Xu}

Department of Civil Engineering, Changzhou University, Changzhou, China

Self-compacting concrete (SCC) is widely used in tunnel linings that are subject to fire risks. During tunnel fires, personnel and structural safety are commonly threatened by the explosive spalling of SCC due to its high strength and high moisture content. Recent studies have suggested that a coating of fire-resistant material can efficiently prevent SCC from spalling during a tunnel fire. In this study, SCC samples coated with a $6 \mathrm{~mm}$ thick layer of silicon dioxide aerogel-cement mortar $\left(\mathrm{SiO}_{2}-\mathrm{ACM}\right)$ were prepared and compared with uncoated samples. The effects of different moisture contents $(0 \%$, $25 \%, 50 \%, 75 \%$ and $100 \%$ ) on the fire resistance of SCC were investigated. The results show that $\mathrm{SiO}_{2}-\mathrm{ACM}$ exhibited excellent mechanical and durability performances as well as low thermal conductivity. During exposure to mimetic tunnel fire, the degree of spalling of SCC increased as moisture content increased. The SCC samples with the SiO ${ }_{2}-\mathrm{ACM}$ coating exhibited much less spalling than those without such coating. After the mimetic tunnel fire, the uncoated SCC samples had almost completely failed in terms of compressive strength, whereas the residual compressive strength of the coated SCC samples was more than $68.6 \%$ even for the SCC with $100 \%$ moisture content. Therefore, a SiO ${ }_{2}-\mathrm{ACM}$ coating provides an attractive means by which to enhance the behaviour of SCC during a tunnel fire.

\begin{tabular}{ll}
\multicolumn{2}{l}{ Notation } \\
$f_{\text {bending }}$ & bending strength \\
$f_{\text {bonding }}$ & bonding strength \\
$f_{\mathrm{c}}$ & compressive strength \\
$I$ & current \\
$K$ & thermal conductivity \\
$L$ & length of cupronickel alloy wire \\
$m_{0}$ & the mass of samples when the samples reached $0 \%$ \\
& moisture content \\
$m_{100}$ & the mass of samples when the samples reached \\
& $\begin{array}{l}100 \% \text { moisture content } \\
m_{x}\end{array}$ \\
$T$ & the mass of samples when the samples reached \\
$t$ & objective moisture content \\
$U$ & temperature \\
$\rho_{\mathrm{m}}$ & time
\end{tabular}

\section{Introduction}

The rapid increase in the rate of industrialisation and urbanisation has led to a great worldwide demand for tunnel development to alleviate the pressure of overland transportation (Ntzeremes and Kirytopoulos, 2018). However, serious tunnel fire accidents are increasing alongside this development, which causes road casualties and massive rehabilitation costs.
For example, in China more than 161 tunnel fire accidents occurred between 2000 and 2016, of which 40 cases caused damage to the tunnel and 27 cases resulted in casualties (Ren et al., 2019). For this reason, the safety of tunnel concrete structures exposed to fire has become a major concern all over the world.

Tunnel fire accidents are often caused by car collisions which result in the burning of organic substances (e.g. gasoline). The maximum heat release rate of a typical hydrocarbon fire (i.e. more than $100 \mathrm{MW}$ ) is ten times higher than that of a building fire (Chatris et al., 2001; Mudan, 1984). The temperature can rapidly reach over $1000^{\circ} \mathrm{C}$ within $10 \mathrm{~min}$ of the start of a tunnel fire (Ingason, 2009). The high temperature gradients and the rapid heating lead to a sharp increase in pore pressures due to the explosive formation of water vapour and thermally induced high compressive stresses inside the tunnel concrete structures, resulting in the spalling of concrete from tunnel linings, threatening the integrity of the concrete structure or even leading to the collapse of the tunnel (Donatello et al., 2014; Hertz, 1992; Huang et al., 2017; Zhang and Davie, 2013; Zhao et al., 2017).

The popularity of self-compacting concrete (SCC) has been on a steady incline owing to its superior performance in 
tunnel lining applications (Samimi et al., 2019; Sideris and Manita, 2013). However, previous studies have suggested that the performance of SCC during exposure to tunnel fire is deficient (Liu et al., 2008; Xargay et al., 2018a, 2018b). Persson (2004) discovered that at high temperatures the explosive spalling of columns with SCC took place easily. Liu et al. (2008) also reported that the spalling issue of SCC after fire was a prevalent problem. In addition, SCC showed a decrease in strength when it was subjected to high temperatures (Uysal and Tanyildizi, 2012). Therefore, techniques to improve the fire resistance of SCC are desirable for its application in tunnel linings.

In recent years, a series of studies have been undertaken to increase the fire resistance of concrete during tunnel fire accidents (Meng et al., 2016; Robert and Colina, 2009; Samson et al., 2016; Sobia and Azmi, 2015). Previous studies have suggested that a protective coating layer has potential to insulate the concrete structures from fire and alleviate spalling (Donatello et al., 2014; Kim et al., 2010; Li et al., 2013; Wang et al., 2017). Bezgin (2015) reported on the required thickness of the cement and volcanic ash-based protection layer for high-strength concrete tunnel segments. Sakkas et al. (2014) reported on the fire resistance of potassium-based geopolymer used as passive fire protection for concrete tunnels linings. Ji et al. (2013) developed a new fire-resistant technology with nanoclay-reinforced intumescent coating to repair reinforced concrete beams, showing that this coating system could enhance fire resistance. Among all the coating techniques, a cement-based thermal insulation mortar mixed with adiabatic aggregate has been widely considered as a potential coating layer for SCC to increase fire resistance due to its convenience during construction and excellent bonding strength with SCC (Cülfik and Özturan, 2002; Farzadnia et al., 2013; Heikal et al., 2015; Ibrahim et al., 2012).

Silicon dioxide $\left(\mathrm{SiO}_{2}\right)$ aerogel is an ideal heat-insulating aggregate with an ultralight density of $0.001-0.5 \mathrm{~g} / \mathrm{cm}^{3}$, high porosity of $95-99 \cdot 8 \%$, super-low thermal conductivity of $0 \cdot 005-0 \cdot 018 \mathrm{~W} /(\mathrm{m} \mathrm{K})$ at $25^{\circ} \mathrm{C}$ and 1 atm (Jia et al., 2018; Koebel et al., 2011). Ibrahim et al. (2014) examined the energy behaviour of multi-layer exterior wall structures covered with different insulating coatings, showing that the silicon dioxide aerogel-based insulating coating revealed better thermal performance than expanded polystyrene and glass wool insulating materials. Silicon dioxide aerogel cement mortar $\left(\mathrm{SiO}_{2}-\mathrm{ACM}\right)$ also showed excellent thermal insulation performance with low thermal conductivity of $0.084 \mathrm{~W} /(\mathrm{m} \mathrm{K})$ (de Fátima Júlio et al., 2016a), $0.086 \mathrm{~W} /(\mathrm{m} \mathrm{K})$ (Liu et al., 2016), $0.085 \mathrm{~W} /(\mathrm{m} \mathrm{K})$ (de Fátima Júlio et al., 2016b), and proper strength for coating materials. Although the use of $\mathrm{SiO}_{2}-\mathrm{ACM}$ as a thermal insulation material has been rapidly increasing in the construction industry (Jia et al., 2018), no study has been reported to date on the performance of $\mathrm{SiO}_{2}-\mathrm{ACM}$ exposure to tunnel fire. This important research gap needs to be addressed through additional studies on $\mathrm{SCC}$ coated with $\mathrm{SiO}_{2}-\mathrm{ACM}$.
The moisture content of concrete in tunnel linings is always influenced by the environment and climate (Choe et al., 2019; Dauti et al., 2018; Kallel et al., 2017). Van der Heijden et al. (2007) suggested that the moisture inside the concrete is a key factor in the spalling mechanism. When the critical value of moisture content is exceeded, explosive spalling can occur at high temperature. Lai et al. (2014) indicated that the increasing moisture content of high-performance concrete resulted in the increasing frequency of explosive spalling of the concrete and more severe damage. A similar conclusion was obtained from the experiments of Chan et al. (1999) and Ma et al. (2018). Therefore, it is important to investigate the influence of moisture content on the behaviour of concrete exposed to fire.

Because of the few explorative and experimental studies reported to date on the behaviour of $\mathrm{SCC}$ coated with $\mathrm{SiO}_{2}-$ ACM exposed to tunnel fire, the study presented in this paper investigated the fire resistance of SCC coated with $\mathrm{SiO}_{2}-\mathrm{ACM}$. The paper initially presents a summary of the experimental programme, including material and specimen properties and testing procedures, and then follows this with the results of the experimental programme. Detailed discussions on the results are then presented, in which the behaviour of coated and uncoated SCC samples during exposure to tunnel fire are discussed along with the moisture content of concrete.

\section{Experimental programme}

\section{Materials}

Ordinary Portland cement was used in this study. Silica fume (SF) and fly ash (FA) were added to improve the performances of the matrix. Table 1 shows the chemical properties and specific gravity of Portland cement, SF, slag and FA. Titanium dioxide $\left(\mathrm{TiO}_{2}\right)$ powder was used as a high-temperature infrared inhibitor. Redispersible latex powder (RLP) and cellulose ether (CE) were used to increase the workability of mortar and as a thickening agent, respectively. The physical characteristics of natural sand and commercial silicon dioxide aerogel are shown in Table 2. Polypropylene fibre (length: $12 \mathrm{~mm}$ ) was used to enhance the crack resistance of mortar. An air-entraining admixture (AEA) was added to improve the workability and density of the mortar.

Table 1. Chemical properties of Portland cement, SF, slag and FA

\begin{tabular}{lrrrc} 
Component & Cement & \multicolumn{1}{c}{ SF } & Slag & FA \\
Calcium oxide $(\mathrm{CaO})$ & 60.81 & 0.23 & 26.46 & 3.82 \\
Silicon dioxide $\left(\mathrm{SiO}_{2}\right)$ & 21.32 & 86.18 & 32.36 & 52.5 \\
Aluminium oxide $\left(\mathrm{Al}_{2} \mathrm{O}_{3}\right)$ & 7.32 & 1.08 & 17.02 & 28.35 \\
Iron oxide $\left(\mathrm{Fe}_{2} \mathrm{O}_{3}\right)$ & 3.84 & 0.93 & 1.31 & 3.67 \\
Magnesium oxide $(\mathrm{MgO})$ & 1.16 & 0.78 & 7.88 & 0.78 \\
Sulfur trioxide $\left(\mathrm{SO}_{3}\right)$ & 2.07 & 0.84 & 0.68 & 0.84 \\
Potassium oxide $\left(\mathrm{K}_{2} \mathrm{O}\right)$ & 0.65 & - & 0.96 & 1.69 \\
Titanium dioxide $\left(\mathrm{TiO}_{2}\right)$ & 0.28 & - & 0.89 & 0.87 \\
Manganese oxide $(\mathrm{MnO})$ & 0.15 & 0.78 & 0.45 & 0.18 \\
Specific gravity & 3.15 & 2.2 & 2.84 & 2.18 \\
& & & &
\end{tabular}


Table 2. Physical characteristics of the aggregates

\begin{tabular}{lcc} 
Aggregates & Aerogel & Sand \\
\hline Maximum size: $\mathrm{mm}$ & 2 & $2 \cdot 36$ \\
Fineness modulus & - & $2 \cdot 4$ \\
Particle density: $\mathrm{kg} / \mathrm{m}^{3}$ & 125 & 2680
\end{tabular}

\section{Specimen preparation}

\section{$\mathrm{SiO}_{2}$-ACM specimens}

The $\mathrm{SiO}_{2}$-ACM was prepared in a two-step mixing process using a cement mixer. Initially, cement, sand, SF and aerogel particles were mixed in a 5 litre mixing pan for $60 \mathrm{~s}$. Subsequently, the superplasticiser (polycarboxylic acid waterreducer, PCA) was added for another 20-30 s. The mixture was mixed for a total time of $180 \mathrm{~s}$. The mix proportion of $\mathrm{SiO}_{2}-\mathrm{ACM}$ is given in Table 3, in which the $\mathrm{SiO}_{2}-\mathrm{ACM}$ was designed according to Liu et al. (2016).

\section{SCC specimens}

In order to study the effect of $\mathrm{SiO}_{2}-\mathrm{ACM}$ on the explosive thermal spalling of SCC in tunnel fire, SCC samples were prepared. The mix proportion of SCC was according to Chinese standard JGJ/T 283-2012 (CNS, 2012b), as shown in Table 4. First, the aggregates (sand and gravel) were put into the mixer and dry stirred for $30 \mathrm{~s}$, then half of the water was added and stirred for $30 \mathrm{~s}$ next, the cementitious materials (cement, FA, $\mathrm{SF}$ and slag) were added and stirred for a further $30 \mathrm{~s}$, before the water-reducing agent and remaining water were added and stirred for a final $30 \mathrm{~s}$. After casting, the SCC samples were filled into cubic moulds $\left(150 \times 150 \times 150 \mathrm{~mm}^{3}\right)$ and cured in a standard curing room ( $>95 \% \mathrm{RH}$ and $20 \pm 2^{\circ} \mathrm{C}$ ) for $24 \mathrm{~h}$ before demoulding. After demoulding, the samples were cured in the standard curing room for $28 \mathrm{~d}$. The performances of SCC are shown in Table 5.

The different moisture contents of the SCC were controlled. After curing, samples were dried in an oven at $105^{\circ} \mathrm{C}$ until the mass of each sample reached constant (mass value recorded as $\left.m_{0}\right)$. Under this status, the sample reached $0 \%$ moisture content. Subsequently, the samples were stored in a water tank for $72 \mathrm{~h}$. Then the samples were taken out, the additional moisture wiped from the surface, and weighed (mass valued recorded as $\left.m_{100}\right)$. Under this status, the sample reached $100 \%$ moisture content. Then the samples were stored in the oven again until the mass of the samples reached $m_{x}$. The moisture content $\left(\rho_{\mathrm{m}}\right)$ can be calculated by Equation 1 (Chan et al., 1999; Sideris and Manita, 2013). In this study, samples with $0,25,50,75$ and $100 \%$ moisture content were prepared. The samples were sealed with plastic film to maintain the moisture when the designed moisture content was reached.

1. $\rho_{\mathrm{m}}=\frac{m_{x}-m_{0}}{m_{100}-m_{0}}$

\section{Composite of $\mathrm{SiO}_{2}-\mathrm{ACM}$ and SCC}

A layer of $6 \mathrm{~mm}$ thick $\mathrm{SiO}_{2}-\mathrm{ACM}$ was applied the SCC concrete cubes, as shown in Figure 1. Before the thermal spalling tests were performed, the specimens were cured in a standard curing room $\left(\mathrm{RH}>95 \%, 20 \pm 2^{\circ} \mathrm{C}\right)$ for another $28 \mathrm{~d}$.

\section{Test methodologies}

\section{Properties of $\mathrm{SiO}_{2}-\mathrm{ACM}$ and SCC}

The bending strength and compressive strength of $\mathrm{SiO}_{2}-\mathrm{ACM}$ were tested according to the Chinese standard JGJ/T 70-2009 (CNS, 2009). The prismatic samples $\left(40 \times 40 \times 160 \mathrm{~mm}^{3}\right)$ were used to test the bending strength, and the cubic specimens $\left(70.7 \times 70.7 \times 70.7 \mathrm{~mm}^{3}\right)$ were used to test for the compressive strength. The thermal conductivity was measured using the hot-wire method (CNS, 2015). In the thermal conductivity test, cupronickel $(\mathrm{Cu} / \mathrm{Ni})$ alloy wire with a length of $73 \mathrm{~mm}$ and a diameter of $0 \cdot 127 \mathrm{~mm}$ was used. The thermal conductivity $(K)$ was calculated using Equation 2.

2. $K=\frac{(U I) /(4 \pi L)}{(\Delta T) / \Delta(\ln t)}$

where $U$ and $I$ are the voltage $(1 \mathrm{~V})$ and current $(0 \cdot 23 \mathrm{~A})$, respectively; $L$ is the length of the cupronickel alloy wire; $T$ and $t$ are the temperature $\left({ }^{\circ} \mathrm{C}\right)$ and time (s), respectively.

Table 3. Mix proportion of $\mathrm{SiO}_{2}-\mathrm{ACM}: \mathrm{g}$

\begin{tabular}{|lccccccccccc} 
Aerogel & Cement & Water & Sand & SF & FA & PCA & Titanium dioxide & CE & RLP & Fibre & AEA \\
\hline 12.29 & 98.04 & 58.54 & 81.75 & 10.89 & 27.48 & 2.04 & 13.65 & 0.83 & 2.73 & 0.41 & 1.37 \\
\hline
\end{tabular}

Table 4. Mix proportions of C40 self-compacting concrete: $\mathrm{kg} / \mathrm{m}^{3}$

\begin{tabular}{|ccccccccc|} 
Gravel & Cement & Sand & FA & Slag & SF & PCA & AEA & Water \\
\hline 804 & 318 & 838 & 132.5 & 53 & 26.5 & 5.3 & 0.53 & 175 \\
\hline
\end{tabular}


Effect of moisture content on tunnel fire resistance of self-compacting concrete coated with aerogel mortar

Wang, Zhu, Yu et al.
Table 5. The performances of SCC

\begin{tabular}{|c|c|c|c|c|c|}
\hline & \multicolumn{4}{|c|}{ Workability } & \multirow{2}{*}{$\begin{array}{l}f_{\mathrm{c}} \text { at } \\
28 \mathrm{~d}: \\
\mathrm{MPa}\end{array}$} \\
\hline & $\begin{array}{l}\text { Slump- } \\
\text { flow: } \mathrm{mm}\end{array}$ & $\begin{array}{l}\text { J-ring } \\
\text { flow: } \mathrm{mm}\end{array}$ & $\begin{array}{c}\text { Passing } \\
\text { ability: } \mathrm{mm}\end{array}$ & $\begin{array}{c}\text { Segregation: } \\
\%\end{array}$ & \\
\hline Actual & 765 & 720 & 45 & $8 \cdot 71$ & 43 \\
\hline
\end{tabular}

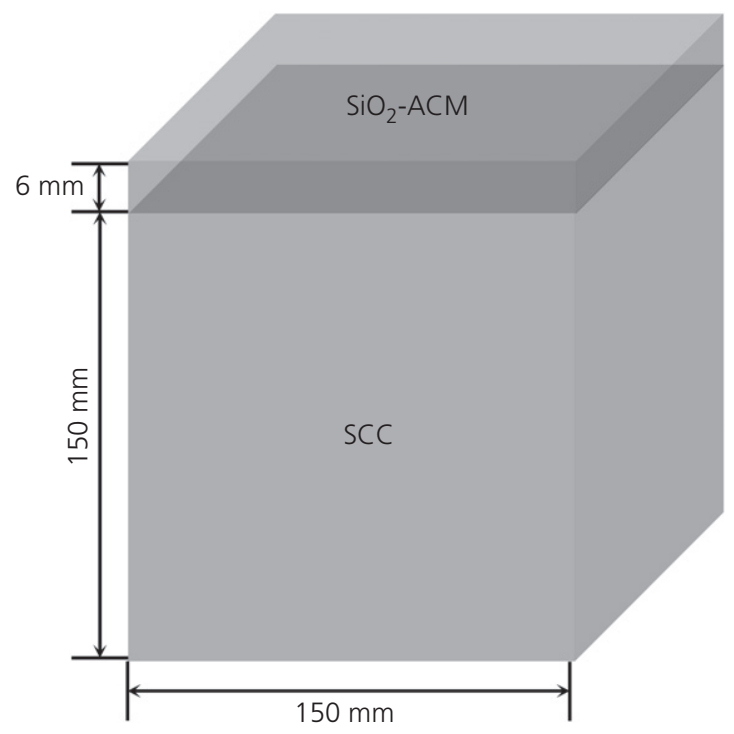

Figure 1. Schematic of SCC coated with $\mathrm{SiO}_{2}-\mathrm{ACM}$

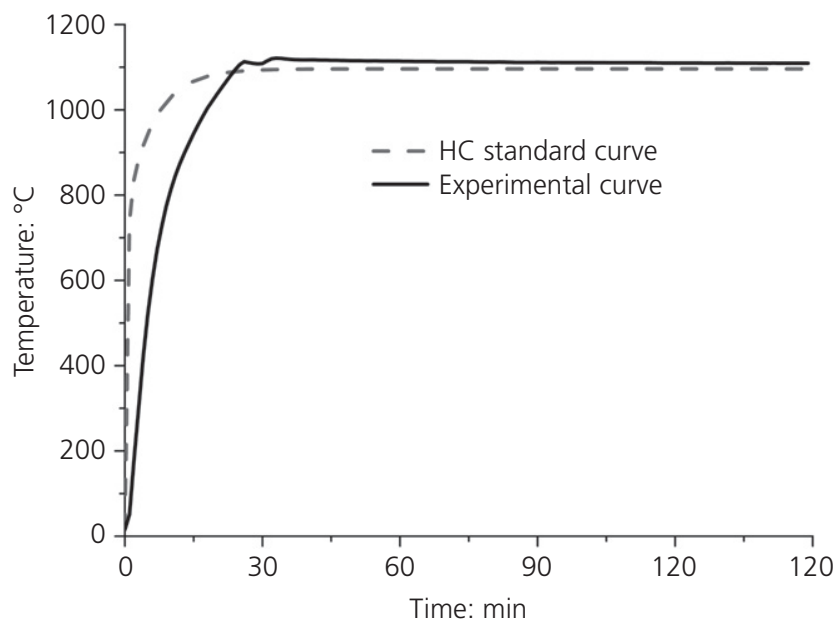

Figure 2. Experimental and $\mathrm{HC}$ standard curves of tunnel fire
The SEM analysis was carried out using a scanning electron microscope (SEM, FEI Nova NanoSEM 230) at an accelerating voltage of $10 \mathrm{kV}$ and a working distance of around $5 \mathrm{~mm}$.

The measurement of the compressive strength of SCC was performed according to the Chinese standard GB/T 50081-2002 (CNS, 2002).

\section{Tunnel fire simulation}

The side surfaces of the composite specimens were sealed with $50 \mathrm{~mm}$ rock wool in order to ensure that a single side of the specimen was subjected to a high temperature, and that the surface with $\mathrm{SiO}_{2}-\mathrm{ACM}$ coating was exposed. Then the specimens were put into a bogie-hearth resistance furnace (RTD-45-13, Jiangsu Jinhuan Test Equipment Co., Ltd), heated up to $1100^{\circ} \mathrm{C}$ in $30 \mathrm{~min}$ and kept at this temperature for $2 \mathrm{~h}$. Subsequently, the samples were cooled down to the ambient temperature in the furnace. This mimetic tunnel fire was designed according to the HC standard tunnel fire rising temperature curve (CNS, 2012a). The experimental and HC standard curve are shown in Figure 2.

\section{Results and discussion}

\section{Properties of $\mathrm{SiO}_{2}-\mathrm{ACM}$}

The mechanical and durable properties of $\mathrm{SiO}_{2}-\mathrm{ACM}$ were measured as shown in Table 6 . The compressive, bending and bonding strengths of $\mathrm{SiO}_{2}-\mathrm{ACM}$ at $28 \mathrm{~d}$ were $3 \cdot 5,0 \cdot 8$ and $1.5 \mathrm{MPa}$, respectively. The results obtained were in agreement with the existing literature (Liu et al., 2016), with the exception of Gao et al. (2014). Besides this, the measured dry density of $\mathrm{SiO}_{2}$-ACM was $668 \mathrm{~kg} / \mathrm{m}^{3}$, which was about half that ascertained in other research (Liu et al., 2016). Thermal conductivity is one of the main properties of $\mathrm{SiO}_{2}-\mathrm{ACM}$ in isolating high temperature. It was measured on the ACM specimens $\left(22 \times 32 \times 105 \mathrm{~mm}^{3}\right)$ using the hot-wire method. A low thermal conductivity of $0 \cdot 185 \mathrm{~W} /(\mathrm{m} \mathrm{K})$ was gained, which was calculated using Equation 1. By contrast, the thermal conductivity of cement mortar without aerogel is as high as $0.533 \mathrm{~W} /(\mathrm{m} \mathrm{K})$ (Kim et al., 2013). Hence, it can be seen that prepared $\mathrm{SiO}_{2}-$ ACM has excellent thermal insulation properties.

Liu et al. (2016) successfully developed a kind of insulating aerogel mortar. When the volume content of aerogel was $60 \%$, the density, thermal conductivity, compressive and flexural strengths of aerogel mortar were $1231 \mathrm{~kg} / \mathrm{m}^{3}, 0 \cdot 1524 \mathrm{~W} /(\mathrm{m} \mathrm{K})$,

Table 6. Mechanical and durable properties of ACM before and after frost resistance resistance

\begin{tabular}{|c|c|c|c|c|c|c|c|c|c|}
\hline \multicolumn{6}{|c|}{ Mechanical properties: MPa } & \multicolumn{4}{|c|}{ Durability } \\
\hline \multicolumn{2}{|l|}{$f_{\mathrm{c}}$} & \multicolumn{2}{|c|}{$f_{\text {bending }}$} & \multicolumn{2}{|c|}{$f_{\text {bonding }}$} & \multirow{2}{*}{$\begin{array}{l}\text { Water resistance: } \\
\mathrm{h}\end{array}$} & \multirow{2}{*}{$\begin{array}{c}\text { Acid resistance: } \\
\mathrm{h}\end{array}$} & \multirow{2}{*}{$\begin{array}{c}\text { Moisture resistance: } \\
\mathrm{h}\end{array}$} & \multirow{2}{*}{$\begin{array}{c}\text { Frost resistance: } \\
\text { times }\end{array}$} \\
\hline Before & After & Before & After & Before & After & & & & \\
\hline $3 \cdot 5$ & $3 \cdot 0$ & 0.8 & 0.6 & $1 \cdot 5$ & $1 \cdot 2$ & $\geq 720$ & $\geq 360$ & $\geq 720$ & $\geq 50$ \\
\hline
\end{tabular}


2.15 $\mathrm{MPa}$ and 0.45 $\mathrm{MPa}$, respectively. Gao et al. (2014) also reported on a lightweight insulating aerogel mortar with a density of $1000 \mathrm{~kg} / \mathrm{m}^{3}$, a thermal conductivity of $0.26 \mathrm{~W} /(\mathrm{m} \mathrm{K})$, and a compressive strength of $8.3 \mathrm{MPa}$ at an aerogel content of $60 \mathrm{vol} . \%$.

Compared to other aerogel insulated mortars, the $\mathrm{SiO}_{2}-\mathrm{ACM}$ prepared in this research has lower density, lower thermal conductivity and similar strength. Moreover, all the mechanical and durable properties of $\mathrm{SiO}_{2}-\mathrm{ACM}$ meet the requirements of Chinese standard GB 28375-2012 (CNS, 2012a). This confirmed that $\mathrm{SiO}_{2}-\mathrm{ACM}$ has the potential to be used as a fireresistant coating.

\section{Explosive spalling of SCC specimens after tunnel fire}

Figure 3 shows the degree of explosive spalling of SCC specimens with $0,25,50,75$ and 100\% moisture content after mimetic tunnel fire. It can be seen that the explosive spalling of uncoated SCC was severe with an increased moisture content of over $25 \%$. Nevertheless, very slight spalling of $\mathrm{SCC}$ with $\mathrm{SiO}_{2}-\mathrm{ACM}$ coating was observed with the increased moisture content. Therefore, the $\mathrm{SiO}_{2}-\mathrm{ACM}$ coating enhances the resistance of SCC to explosive spalling during tunnel fire.

The relationship between the moisture content of SCC and spalling initiation time, spalling duration, the number of loud voices (used to categorise the degree of explosive spalling) and spalling initiation temperature was investigated, as shown in Table 7.

It was observed that the spalling initiation time and temperature for spalling occurrence decreased from $11 \mathrm{~min}$ to $5 \mathrm{~min}$ and from $845^{\circ} \mathrm{C}$ to $498^{\circ} \mathrm{C}$, respectively, when the moisture content of SCC increased from 50 to $100 \%$. Zhao et al. (2014) suggested that damage appears when the surface temperature reaches $555.5^{\circ} \mathrm{C}$, but no spalling occurs in the whole process of heating up to $600^{\circ} \mathrm{C}$. This indicated that the increase in moisture content results in the explosive spalling of SCC occurring at an earlier time and at a lower temperature, due to the build-up of pore pressure by steam (Poon et al., 2003). The vapour pressure is mainly caused by internal free water of concrete (Peng and Huang, 2008). Chan et al. (1999) also found that moisture content and strength are the two main factors governing thermally induced explosive spalling of concrete. The spalling duration and number of loud voices increased with the increase in moisture content, while the highest values were at $75 \%$ of moisture content. The reason for this is that the explosive spalling of SCC specimens occurred on a large scale when the moisture content of SCC was $100 \%$. As a consequence, although the spalling duration and the number of loud voices were less than that with $75 \%$ moisture content, the degree of explosion damage of SCC with $100 \%$ moisture content was more obvious (Figure 3).
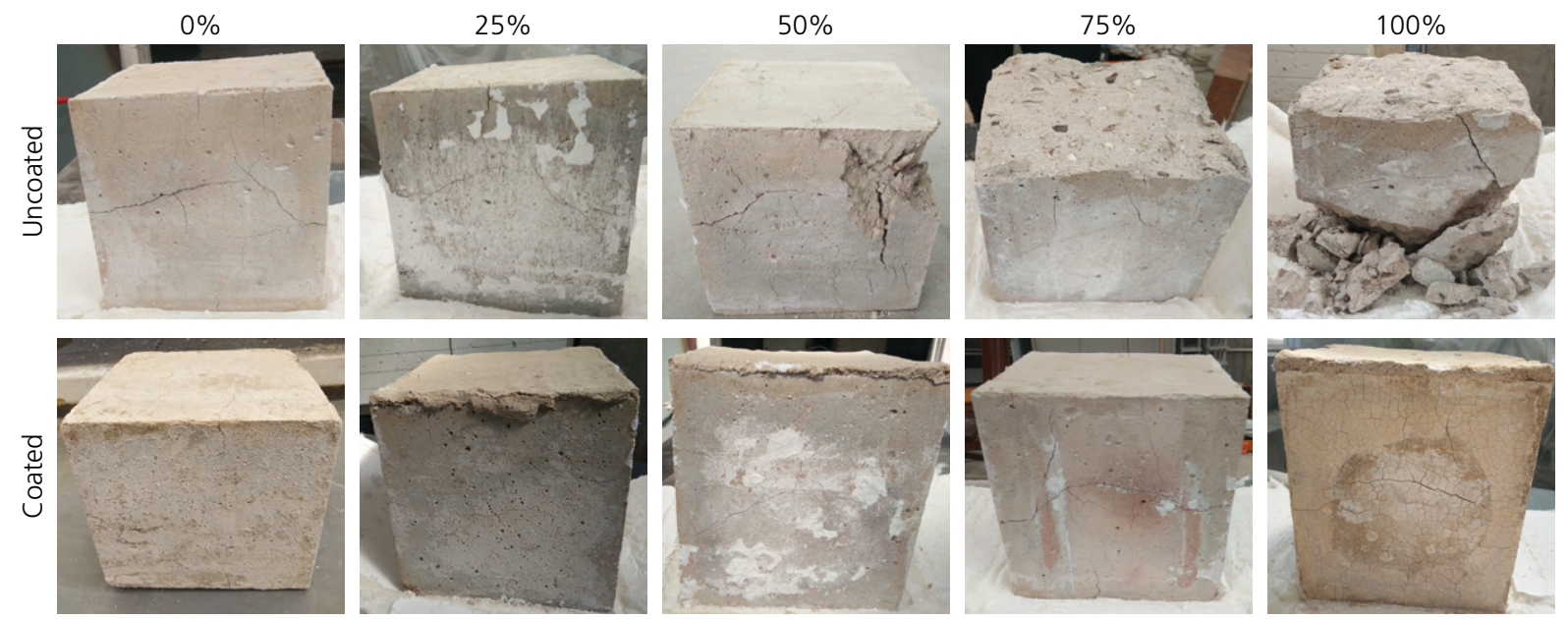

Figure 3. Images of SCC samples with 0-100\% moisture contents after mimetic tunnel fire

Table 7. Explosive spalling parameters of SCC not coated with $\mathrm{SiO}_{2}-\mathrm{ACM}$ at different moisture contents

\begin{tabular}{|lcccr}
$\begin{array}{l}\text { Moisture } \\
\text { content: \% }\end{array}$ & $\begin{array}{c}\text { Spalling initiation time: } \\
\text { min }\end{array}$ & $\begin{array}{c}\text { Temperature for spalling } \\
\text { occurrence: }{ }^{\circ} \text { C }\end{array}$ & $\begin{array}{c}\text { Spalling duration: } \\
\text { min }\end{array}$ & $\begin{array}{c}\text { Number of loud } \\
\text { voices }\end{array}$ \\
\hline 50 & 11 & 845 & 2 & 8 \\
75 & 9 & 625 & 14 & 120 \\
100 & 5 & 498 & 9 & 59
\end{tabular}


Magazine of Concrete Research

Volume 73 Issue 20
Effect of moisture content on tunnel fire

resistance of self-compacting concrete

coated with aerogel mortar

Wang, Zhu, Yu et al.
The explosive spalling of SCC was caused by the production of a large amount of water vapour at high temperature due to the high moisture content in the internal SCC, thus producing greater vapour pressure in the concrete. Furthermore, the higher the moisture content in SCC, the greater the vapour pressure produced in the specimen at the same temperature.

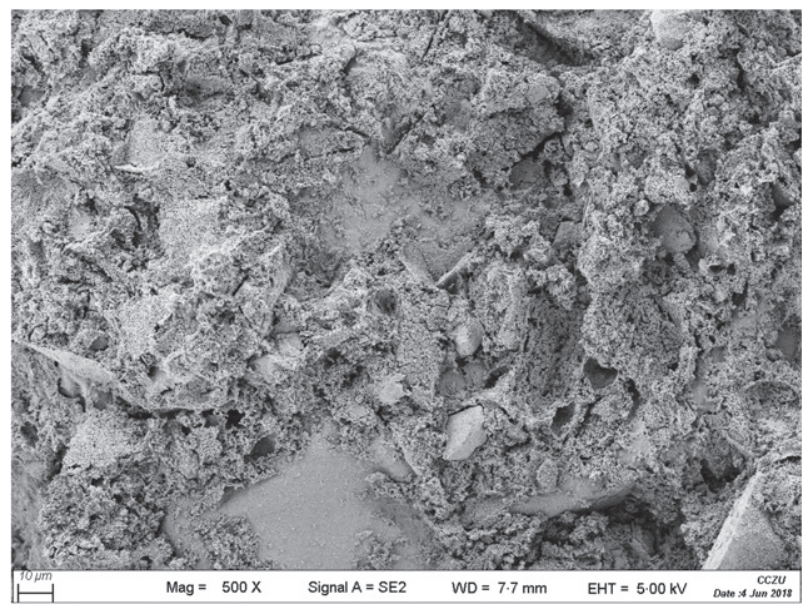

(a)

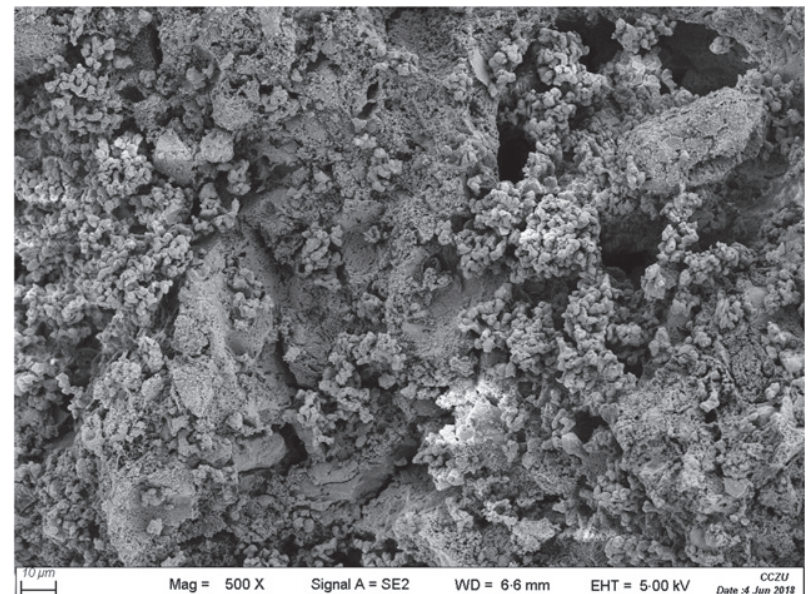

(c)

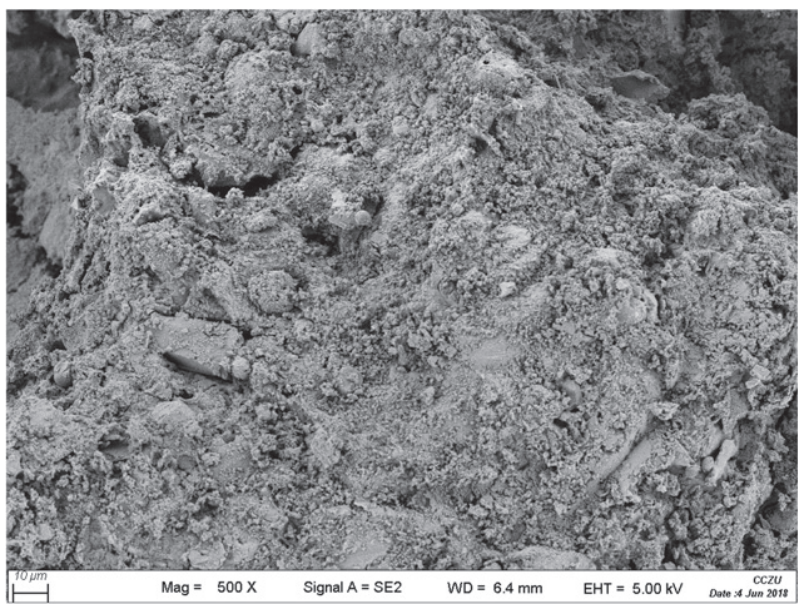

(b)

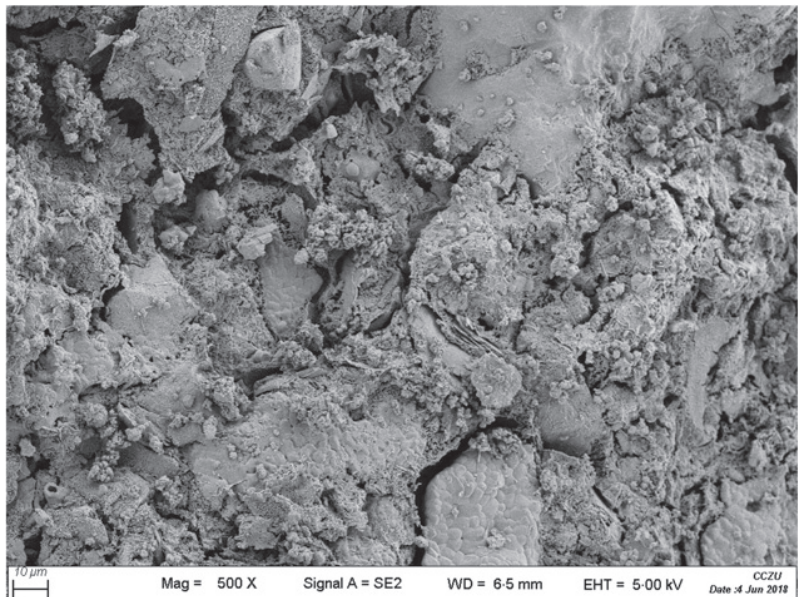

(d)

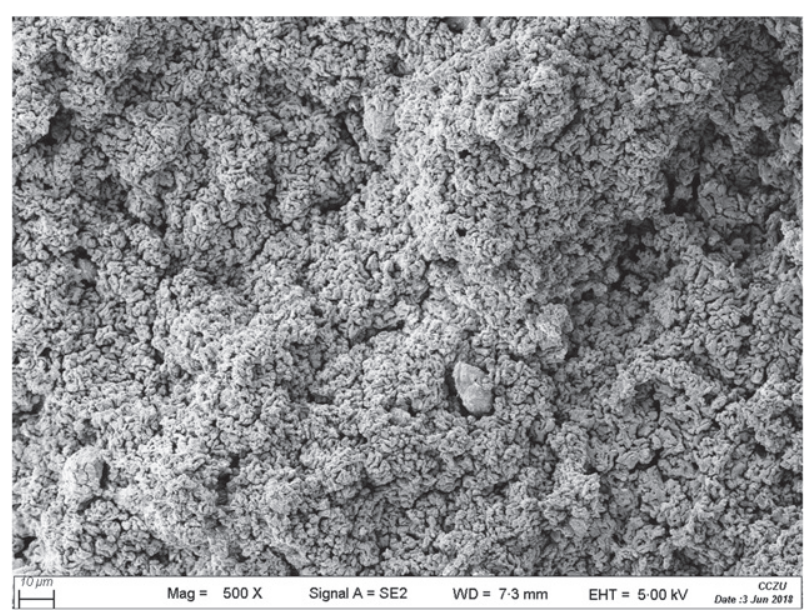

(e)

Figure 4. SEM photographs of SCC uncoated mortar with different moisture contents after mimetic tunnel fire: (a) $0 \%$; (b) $25 \%$; (c) $50 \%$; (d) $75 \%$; (e) $100 \%$ 
Hertz (1992) also found that the risk of spalling increases with the increase of the heating rate and the moisture content of concrete. When the water vapour in a specimen reached a certain degree, the sample would burst, leading to the explosive spalling of SCC (Zhao et al., 2014). However, the use of $\mathrm{SiO}_{2}-$ ACM as a coated layer on the surface of SCC could solve this problem, as shown in Figure 3.

\section{SEM analysis of $\mathrm{SiO}_{2}-\mathrm{ACM}$ and SCC specimens}

Figure 4 presents SEM images of the SCC specimens without coating at different moisture contents after being subjected to mimetic tunnel fire with $\times 500$ magnification. It can be seen that more severe cracks and porous structure can be observed with the increased moisture content. When the moisture content of SCC was at 0 or $25 \%$, no visible internal cracks of the sample could be distinguished. When the moisture content was at 50 and $75 \%$, the crack patterns of the SCC samples were more pronounced, and the concrete matrix had strongly deteriorated. A very loose structure was observed when the moisture content was $100 \%$. As Figure 3 shows, compared with uncoated $\mathrm{SiO}_{2}$-ACM specimens, the SCC samples protected by the $\mathrm{SiO}_{2}-\mathrm{ACM}$ maintained high structural integrity, which would lead to low compressive strength of the SCC after tunnel fire. SEM examinations also certified that a high moisture content would cause spalling of SCC not coated with $\mathrm{SiO}_{2}-\mathrm{ACM}$ after tunnel fire, because the higher the moisture content was, the looser the SCC structure was. A similar observation has been made in previous studies (Hertz, 1992; Liu et al., 2018).

The SEM images of $\mathrm{SiO}_{2}-\mathrm{ACM}$ before and after mimetic tunnel fire are shown in Figure 5. It is well known that silicon dioxide aerogel possesses great potential in the field of building insulation because of its ultra-low thermal conductivity, which arises from its unique three-dimensional nano-porous structure (Baetens et al., 2011; Cuce et al., 2014). However, aerogel particles changed to opaque white and atrophied significantly after exposure to tunnel fire, thus leading to the enlargement of the interfacial transition zone (ITZ) of silicon dioxide aerogel and cement matrix (Figure 5(c)). The atrophy of aerogel particles is primarily caused by the destruction of the three-dimensional nano-porous structure of aerogel (Huang et al., 2017; Li et al., 2016). However, Huang et al. (2017) observed that the dehydroxylation of aerogel particles begins occurring when the heating temperature increases to $1100^{\circ} \mathrm{C}$ for more than $30 \mathrm{~min}$, implying that the structure of aerogel particles could maintain some stability at high temperature, even at tunnel fire temperatures. But as time goes on, the structure of the aerogel particles is destroyed.

For pure silicon dioxide aerogel particles, the pores inside the particles totally collapsed and were fused together at $1100^{\circ} \mathrm{C}$ for $1.5 \mathrm{~h}$, as referred to by Huang et al. (2017). In this case, even though the atrophy of the aerogel particles was still observed, they retained a three-dimensional structure after $1100^{\circ} \mathrm{C}$ for $1 \mathrm{~h}$ (Figure 5(b)). It was deduced that the existence of the cement matrix might postpone the atrophy of the aerogel particles, thus extending the tunnel fire resistance time, which could be verified in further research.

\section{Residual compressive strength of SCC after tunnel fire}

The residual compressive strength of SCC with different moisture contents after being subjected to high temperatures is plotted in Figure 6. As a function of moisture content, the compressive strength of SCC showed a downward trend for both coated and $\mathrm{SiO}_{2}-\mathrm{ACM}$-coated SCC. Some researchers (Caetano et al., 2019; Shen and Xu, 2019) have also indicated that moisture content has a significant effect on the concrete's mechanical performance. This is because, as the ambient temperature continues to rise, initially the free water in the SCC evaporates and several chemical and physical transformations of the paste and aggregates under high temperature take place, making the cement particles more tightly bound (Khoury, 2002; Luccioni et al., 2003). Consequently, the steam generated by the combined water and the adsorbed water is more difficult to discharge when subjected to high temperatures. In particular, the internal structure of SCC is dense, and a large vapour pressure is generated inside the concrete at a high temperature,

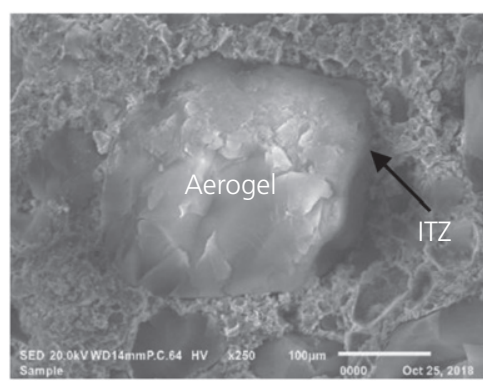

(a)

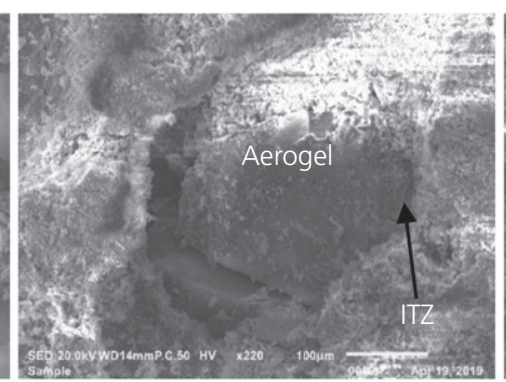

(b)

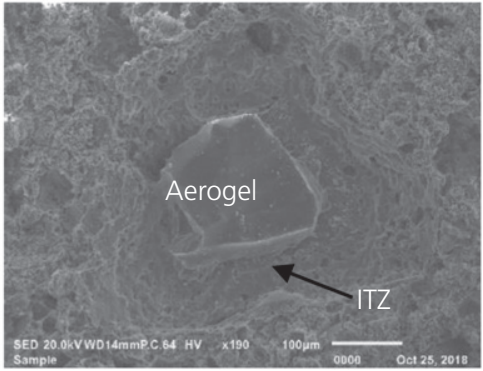

(c)

Figure 5. SEM images of $\mathrm{SiO}_{2}-\mathrm{ACM}$ : (a) before mimetic tunnel fire; (b) after mimetic tunnel fire for $1 \mathrm{~h}$; and (c) after mimetic tunnel fire for $2 \mathrm{~h}$ 


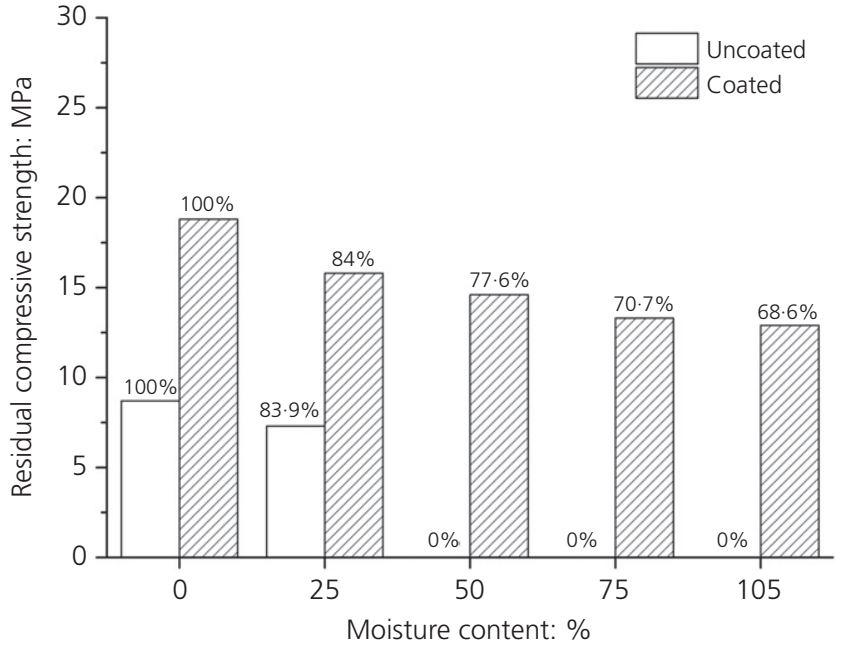

Figure 6. Residual compressive strength of SCC with different moisture content after mimetic tunnel fire

causing cracking of the concrete surface and deterioration in the mechanical properties of SCC.

It is clear that the residual compressive strength of the SCC samples coated with $\mathrm{SiO}_{2}-\mathrm{ACM}$ was much higher than that of the uncoated ones (see Figure 6). The residual compressive strength of SCC samples not coated with $\mathrm{SiO}_{2}-\mathrm{ACM}$ at moisture contents of $50 \%, 75 \%$ and $100 \%$ was considered to be $0 \mathrm{MPa}$ due to the explosive spalling of SCC, whereas the residual compressive strength of SCC samples coated with $\mathrm{SiO}_{2}$-ACM was more than $68.6 \%$ even for SCC samples with $100 \%$ moisture content. Furthermore, the residual compressive strength of coated SCC samples was almost twice as great as the uncoated ones at moisture contents of $0 \%$ and $25 \%$ after high temperature. The above results suggested that the $\mathrm{SiO}_{2-}$ ACM coating provided excellent protection of SCC at high temperature.

\section{Conclusions}

(a) A potential fireproof coating layer, $\mathrm{SiO}_{2}-\mathrm{ACM}$, used in tunnel concrete structures was prepared, of which the dry density was $668 \mathrm{~kg} / \mathrm{m}^{3}$, thermal conductivity was $\sim 0 \cdot 185 \mathrm{~W} /(\mathrm{m} \mathrm{K})$, and mechanical properties (compressive and bend) were excellent.

(b) Moisture content had a significant effect on the explosive spalling of SCC under tunnel fire. The degree of spalling of SCC increased as the moisture content increased, when the moisture content was more than $25 \%$. The residual compressive strength of SCC decreased with the increase of moisture content.

(c) Using $\mathrm{SiO}_{2}-\mathrm{ACM}$ as a coating layer on the surface of SCC could play a crucial role in protecting SCC from spalling under tunnel fire. The SCC samples with $\mathrm{SiO}_{2-}$
ACM coating exhibited much less spalling than those without coating. The residual compressive strength of SCC coated with $\mathrm{SiO}_{2}-\mathrm{ACM}$ was more than $68.6 \%$ even for SCC with $100 \%$ of moisture content.

(d) $\mathrm{SiO}_{2}$-ACM coating feasibly offers an attractive means of enhancing the behaviour of SCC in a tunnel fire.

However, the thickness of the $\mathrm{SiO}_{2}-\mathrm{ACM}$ coating as a protective layer still requires further research.

\section{Acknowledgements}

This work was financially supported by the National Natural Science Foundation of China (No. 51678080 and 51678081), Natural Science Foundation of the Jiangsu Higher Education Institutions of China (No. 18KJB560001) and Postgraduate Research \& Practice Innovation Program of Jiangsu Province (No. SJCX17_0710).

\section{REFERENCES}

Baetens R, Jelle BP and Gustavsen A (2011) Aerogel insulation for building applications: a state-of-the-art review. Energy and Buildings 43(4): 761-769, https://doi.org/10.1016/j.enbuild.2010.12.012.

Bezgin NÖ (2015) An experimental evaluation to determine the required thickness of passive fire protection layer for high strength concrete tunnel segments. Construction and Building Materials 95: 279-286, https://doi.org/10.1016/j.conbuildmat.2015.07.130.

Caetano H, Ferreira G, Rodrigues JPC and Pimienta P (2019) Effect of the high temperatures on the microstructure and compressive strength of high strength fibre concretes. Construction and Building Materials 199: 717-736, https://doi.org/10.1016/j.conbuildmat. 2018.12.074.

Chan SYN, Peng GF and Anson M (1999) Fire behavior of highperformance concrete made with silica fume at various moisture contents. ACI Materials Journal 96(3): 405-409, https://doi.org/ $10.14359 / 640$.

Chatris JM, Quintela J, Folch J et al. (2001) Experimental study of burning rate in hydrocarbon pool fires. Combustion \& Flame 126(1): 1373-1383.

Choe G, Kim G, Yoon M et al. (2019) Effect of moisture migration and water vapor pressure build-up with the heating rate on concrete spalling type. Cement and Concrete Research 116(August): 1-10, https://doi.org/10.1016/j.cemconres.2018.10.021.

CNS (China National Standard) (2002) GB/T 50081-2002: Standard for test method of mechanical properties on ordinary concrete. China National Standard, Shenzen, China.

CNS (2009) JGJ/T 70-2009: Standard for test method of performance on building mortar. China National Standard, Shenzen, China.

CNS (2012a) GB 28375-2012: Fireproof coatings for concrete structure. China National Standard, Shenzen, China.

CNS (2012b) JGJ/T 283-2012: Technical specification for application of self-compacting concrete. China National Standard, Shenzen, China.

CNS (2015) GB/T 10297-2015: Test method for thermal conductivity of nonmetal solid materials - hot-wire method. China National Standard, Shenzen, China.

Cuce E, Cuce PM, Wood CJ and Riffat SB (2014) Toward aerogel based thermal superinsulation in buildings: a comprehensive review. Renewable and Sustainable Energy Reviews 34: 273-299, https://doi.org/10.1016/j.rser.2014.03.017.

Cülfik MS and Özturan T (2002) Effect of elevated temperatures on the residual mechanical properties of high-performance mortar. Cement and Concrete Research 32(5): 809-816, https://doi.org/ 10.1016/S0008-8846(02)00709-3.

Dauti D, Tengattini A, Pont SD et al. (2018) Analysis of moisture migration in concrete at high temperature through in situ neutron 
tomography. Cement and Concrete Research 111(February): 41-55, https://doi.org/10.1016/j.cemconres.2018.06.010.

de Fátima Júlio M, Soares A, Ilharco LM, Flores-Colen I and de Brito J (2016a) Aerogel-based renders with lightweight aggregates: correlation between molecular/pore structure and performance. Construction and Building Materials 124: 485-495, https://doi. org/10.1016/j.conbuildmat.2016.07.103.

de Fátima Júlio M, Soares A, Ilharco LM, Flores-Colen I and de Brito J. (2016b) Silica-based aerogels as aggregates for cement-based thermal renders. Cement and Concrete Composites 72: 309-318, https://doi.org/10.1016/j.cemconcomp.2016.06.013.

Donatello S, Kuenzel C, Palomo A and Fernández-Jiménez A (2014) High temperature resistance of a very high volume fly ash cement paste. Cement and Concrete Composites 45: 234-242, https://doi.org/10.1016/j.cemconcomp.2013.09.010.

Farzadnia N, Abang AAA and Demirboga R (2013) Characterization of high strength mortars with nano alumina at elevated temperatures. Cement and Concrete Research 54: 43-54, https://doi.org/10.1016/ j.cemconres.2013.08.003.

Gao T, Jelle BP, Gustavsen A and Jacobsen S (2014) Aerogelincorporated concrete: an experimental study. Construction and Building Materials 52: 130-136, https://doi.org/10.1016/ j.conbuildmat.2013.10.100.

Heikal M, Ismail MN and Ibrahim NS (2015) Physico-mechanical, microstructure characteristics and fire resistance of cement pastes containing $\mathrm{Al}_{2} \mathrm{O}_{3}$ nano-particles, Construction and Building Materials 91: 232-242, https://doi.org/10.1016/ j.conbuildmat.2015.05.036.

Hertz KD (1992) Danish investigations on silica fume concretes at elevated temperatures. ACI Materials Journal 89(4): 345-347, https://doi.org/10.14359/9750.

Huang D, Guo C, Zhang M and Shi L (2017) Characteristics of nanoporous silica aerogel under high temperature from $950^{\circ} \mathrm{C}$ to $1200^{\circ} \mathrm{C}$. Materials and Design 129(January): 82-90, https://doi. org/10.1016/j.matdes.2017.05.024.

Ibrahim RK, Hamid R and Taha MR (2012) Fire resistance of high-volume fly ash mortars with nanosilica addition, Construction and Building Materials 36: 779-786, https://doi.org/10.1016/ j.conbuildmat.2012.05.028

Ibrahim M, Biwole PH , Wurtz E and Achard P (2014) A study on the thermal performance of exterior walls covered with a recently patented silica-aerogel-based insulating coating. Building and Environment 81: 112-122, https://doi.org/10.1016/j.buildenv.2014. 06.017 .

Ingason H (2009) Design fire curves for tunnels. Fire Safety Journal 44(2): 259-265, https://doi.org/10.1016/j.firesaf.2008.06.009.

Ji G, Li G and Alaywan W (2013) A new fire resistant FRP for externally bonded concrete repair. Construction and Building Materials 42: 87-96, https://doi.org/10.1016/j.conbuildmat.2013.01.008.

Jia G, Li Z, Liu P and Jing Q (2018) Applications of aerogel in cementbased thermal insulation materials an overview. Magazine of Concrete Research 70(16): 822-837, https://doi.org/10.1680/jmacr. 17.00234.

Kallel H, Carré H, La Borderie C, Masson B and Tran NC (2017) Effect of temperature and moisture on the instantaneous behaviour of concrete. Cement and Concrete Composites 80: 326-332, https://doi.org/10.1016/j.cemconcomp.2017.03.021.

Khoury GA (2002) Effect of fire on concrete and concrete structures. Progress in Structural Engineering and Materials 2(4): 429-447, https://doi.org/10.1002/pse.51.

Kim JHJ, Lim YM, Won JP and Park HG (2010) Fire resistant behavior of newly developed bottom-ash-based cementitious coating applied concrete tunnel lining under RABT fire loading. Construction and Building Materials 24(10): 1984-1994, https://doi.org/10.1016/ j.conbuildmat.2010.04.001.
Kim S, Seo J, Cha J and Kim S (2013) Chemical retreating for gel-typed aerogel and insulation performance of cement containing aerogel. Construction and Building Materials 40: 501-505, https://doi.org/ 10.1016/j.conbuildmat.2012.11.046.

Koebel MM, Aegerter MA and Leventis N (2011) Aerogels Handbook. Springer.

Lai H, Wang S and Xie Y (2014) Experimental research on temperature field and structure performance under different lining water contents in road tunnel fire. Tunnelling and Underground Space Technology 43: 327-335, https://doi.org/10.1016/j.tust.2014.05.009.

Li Q, Li Z, Yuan G and Shu Q (2013) The effect of a proprietary inorganic coating on compressive strength and carbonation depth of simulated fire-damaged concrete. Magazine of Concrete Research 65(11): 651-659, https://doi.org/10.1680/macr.12.00119.

Li Z, Cheng X, Shi L et al. (2016) Flammability and oxidation kinetics of hydrophobic silica aerogels. Journal of Hazardous Materials 320 : 350-358, https://doi.org/10.1016/j.jhazmat.2016.07.054.

Liu X, Ye G, De Schutter G, Yuan Y and Taerwe L (2008) On the mechanism of polypropylene fibres in preventing fire spalling in self-compacting and high-performance cement paste. Cement and Concrete Research 38(4): 487-499, https://doi.org/10.1016/ j.cemconres.2007.11.010.

Liu Z, Wang F and Deng Z (2016) Thermal insulation material based on $\mathrm{SiO}_{2}$ aerogel. Construction and Building Materials 122: 548-555, https://doi.org/10.1016/j.conbuildmat.2016.06.096.

Liu JC, Tan KH and Yao Y (2018) A new perspective on nature of fire-induced spalling in concrete. Construction and Building Materials 184: 581-590, https://doi.org/10.1016/j.conbuildmat.2018.06.204.

Luccioni BM, Figueroa MI and Danesi RF (2003) Thermo-mechanic model for concrete exposed to elevated temperatures. Engineering Structures 25(6):729-742, https://doi.org/10.1016/S0141-0296(02) 00209-2.

Ma Q, Guo R, Sun Y et al. (2018) Behaviour of modified lightweight aggregate concrete after exposure to elevated temperatures. Magazine of Concrete Research 70(5): 217-230, https://doi.org/ 10.1680/jmacr.17.00136.

Meng G, Gao B, Zhou J, Cao G and Zhang Q (2016) Experimental investigation of the mechanical behavior of the steel fiber reinforced concrete tunnel segment. Construction and Building Materials 126: 98-107, https://doi.org/10.1016/j.conbuildmat.2016.09.028.

Mudan KS (1984) Thermal radiation hazards from hydrocarbon pool fires. Progress in Energy and Combustion Science 10(1): 59-80, https://doi.org/10.1016/0360-1285(84)90119-9.

Ntzeremes P and Kirytopoulos K (2018) Applying a stochastic-based approach for developing a quantitative risk assessment method on the fire safety of underground road tunnels. Tunnelling and Underground Space Technology 81(December): 619-631, https://doi.org/10.1016/j.tust.2018.08.020.

Peng GF and Huang ZS (2008) Change in microstructure of hardened cement paste subjected to elevated temperatures. Construction and Building Materials 22(4): 593-599, https://doi.org/10.1016/ j.conbuildmat.2006.11.002.

Persson B (2004) Fire resistance of self-compacting concrete, SCC. Materials and Structures/Materiaux et Constructions 37(273): 575-584, https://doi.org/10.1617/13980.

Poon CS, Azhar S, Anson M and Wong YL (2003) Performance of metakaolin concrete at elevated temperatures. Cement and Concrete Composites 25(1): 83-89, https://doi.org/10.1016/S09589465(01)00061-0.

Ren R, Zhou H, Hu Z, He S and Wang X (2019) Statistical analysis of fire accidents in Chinese highway tunnels 2000-2016. Tunnelling and Underground Space Technology 83(December): 452-460, https://doi.org/10.1016/j.tust.2018.10.008.

Robert F and Colina H (2009) The influence of aggregates on the mechanical characteristics of concrete exposed to fire. Magazine of 
Concrete Research 61(5): 311-321, https://doi.org/10.1680/macr 2007.00121.

Sakkas K, Panias D, Nomikos PP and Sofianos Al (2014) Potassium based geopolymer for passive fire protection of concrete tunnels linings. Tunnelling and Underground Space Technology 43: 148-156, https://doi.org/10.1016/j.tust.2014.05.003.

Samimi K, Kamaragi GRD and Roy R (2019) Microstructure, thermal analysis and chloride penetration of self-compacting concrete under different conditions. Magazine of Concrete Research 71(3): 126-143, https://doi.org/10.1680/jmacr.17.00367.

Samson G, Lanos C and Phelipot-mardelé A (2016) A review of thermomechanical properties of lightweight concrete. Magazine of Concrete Research 69(4): 201-216, https://doi.org/10.1680/ jmacr.16.00324.

Shen J and Xu Q (2019) Effect of moisture content and porosity on compressive strength of concrete during drying at $105^{\circ} \mathrm{C}$. Construction and Building Materials 195: 19-27, https:/doi.org/ 10.1016/j.conbuildmat.2018.11.046.

Sideris KK and Manita P (2013) Residual mechanical characteristics and spalling resistance of fiber reinforced self-compacting concretes exposed to elevated temperatures. Construction and Building Materials 41: 296-302, https://doi.org/10.1016/ j.conbuildmat.2012.11.093.

Sobia AQ and Azmi I (2015) Elevated temperature resistance of ultra-high-performance fibre-reinforced cementitious composites. Magazine of Concrete Research 67(17): 923-937, https://doi.org/ 10.1680/macr.14.00134.

Uysal M and Tanyildizi H (2012) Estimation of compressive strength of self compacting concrete containing polypropylene fiber and mineral additives exposed to high temperature using artificial neural network. Construction and Building Materials 27(1): 404-414, https://doi.org/10.1016/j.conbuildmat.2011.07.028. van der Heijden GHA, van Bijnen RMW, Pel $L$ and Huinink HP (2007) Moisture transport in heated concrete, as studied by NMR, and its consequences for fire spalling. Cement and Concrete Research 37(6): 894-901, https://doi.org/10.1016/ j.cemconres.2007.03.004.

Wang F, Wang $M$ and Huo J (2017) The effects of the passive fire protection layer on the behavior of concrete tunnel linings: a field fire testing study. Tunnelling and Underground Space Technology 69(March): 162-170, https://doi.org/10.1016/j.tust. 2017.06.021.

Xargay $\mathrm{H}$, Folino $\mathrm{P}$, Nuñez $\mathrm{N}$ et al. (2018a) Acoustic emission behavior of thermally damaged self-compacting high strength fiber reinforced concrete. Construction and Building Materials 187: 519-530, https://doi.org/10.1016/j.conbuildmat.2018.07.156.

Xargay H, Folino P, Sambataro L and Etse G (2018b) Temperature effects on failure behavior of self-compacting high strength plain and fiber reinforced concrete. Construction and Building Materials 165: 723-734, https://doi.org/10.1016/ j.conbuildmat.2017.12.137.

Zhang HL and Davie CT (2013) A numerical investigation of the influence of pore pressures and thermally induced stresses for spalling of concrete exposed to elevated temperatures. Fire Safety Journal 59: 102-110, https://doi.org/10.1016/j.firesaf.2013.03.019.

Zhao J, Zheng J, Peng G and van Breugel K (2014) A meso-level investigation into the explosive spalling mechanism of highperformance concrete under fire exposure. Cement and Concrete Research 65: 64-75, https://doi.org/10.1016/j.cemconres. 2014.07.010.

Zhao J, Zheng J, Peng G and Sun P (2017) Spalling and cracking modelling of high-performance concrete exposed to elevated temperatures. Magazine of Concrete Research 69(24): 1276-1287, https://doi.org/10.1680/jmacr.16.00139.

\section{How can you contribute?}

To discuss this paper, please submit up to 500 words to the editor at journals@ice.org.uk. Your contribution will be forwarded to the author(s) for a reply and, if considered appropriate by the editorial board, it will be published as a discussion in a future issue of the journal. 